\title{
LUCERNE MANAGEMENT IN A HUMID TEMPERATE CLIMATE
}

\author{
G. S. Robinson \\ M assey University, Palmerston N orth \\ T. М. Аввотт \\ $D S I R$, Kaikohe
}

\section{Summary}

"Wairau" and "Chanticleer" lucernes were subjected to a series of different mowing and grazing treatments. The effects of these treatments were measured in subsequent spring cuts in terms of: (a) Total dry matter yields. (b) Dry matter yields of lucerne. (c) Dry matter yields of other species. Stem height and number were also examined. The experiment confirmed the importance of adequate spelling between successive grazings in the maintenance of a vigorous crop, capable of competing with invading grasses and weeds. There was no significant difference between the two varieties in the way they responded to the grazing treatments. It was clear that lucerne can be a valuable crop in the humid, temperate climate of the North Island.

\section{INTRODUCTION}

IN the past it has been considered that grazing is the best means of utilizing lucerne (M edicago sativa $\mathrm{L}$.) on light land but it has not been recommended elsewhere (Anon., 1958). It has generally been considered that grazing on heavier soils favours grass invasion and thereby increases competition with the lucerne. Hence there has been a common belief that lucerne should be cut rather than grazed wherever it is adequately supplied with moisture, and most North Island growers have been wary of using stock to graze it. They have believed that grazing would shorten the life of the stand.

Recently, however, some farmers have found that wintering stock on lucerne even with feeding out hay or crops on it, can be beneficial. They believe that this management prolongs the productive life of lucerne in that there is less weed and grass growth to compete with the crop. Furthermore, even during the growing season the occasional grazing of lucerne appears to have had no deleterious effect on the subsequent growth, particularly 
where grazing is completed within a few days, and the lucerne is then spelled for some weeks.

The following studies were aimed at providing more detailed information on the behaviour of lucerne under grazing in the Manawatu where the rainfall is approximately $1,000 \mathrm{~mm}$ per year and evenly distributed.

\section{PILOT TRIAL}

The site for the first experiment, which was of a preliminary nature, was on Ohakea silt loam at Massey University. This is not a free-draining soil, but had been intensively tile drained. "Wairau" lucerne was sown in November 1962 and in the next two seasons the following defoliation systems were applied in three replicated blocks: A sickle-bar mower was used cutting at about 2 in. from the ground when the basal shoots were about 1 in. long. Summer grazing took place at the time of the third cut in the other treatments.

(1) 5 hay cuts during the growing season $(5 \mathrm{H})$

(2) 4 hay cuts with a single grazing in the summer (4 HS)

(3) 4 hay cuts with a single grazing at the beginning of winter (4 HW)

(4) 4 hay cuts with extra autumn spell $(4 \mathrm{H})$

By the spring of 1965, effects of the treatments were showing quite clearly. Yields and the botanical composition of the cut material were recorded in the first two cuts of this growing season. These are shown in Table 1.

TABLE 1: MEAN DRY HERBAGE YIELD AND BOTANICAL COMPOSITION NOVEMBER (1ST CUT) AND DECEMBER (2ND CUT) 1965

$$
(\mathrm{kg} / \mathrm{ha})
$$

\begin{tabular}{lrrrrrrr}
\hline $\begin{array}{l}\text { Treat- } \\
\text { ment }\end{array}$ & \multicolumn{2}{c}{ Total } & \multicolumn{2}{c}{ Lucerne } & \multicolumn{2}{c}{ Other Species } \\
& Nov. 1965 & Dec. 1965 & Nov. 1965 & Dec. 1965 & Nov. 1965 & Dec. 1965 \\
\hline 5H & 3,010 & 860 & 650 & 510 & 2,360 & 350 \\
4HS & 4,260 & 2,090 & 3,890 & 2,080 & 310 & 10 \\
4HW & 3,660 & 1,980 & 3,080 & 1,950 & 580 & 40 \\
4H & 3,550 & 1,380 & 2,300 & 1,230 & 1,250 & 150 \\
LSD 5\% & 570 & 350 & 610 & 460 & 690 & 140 \\
$-\quad 1 \quad \%$ & 860 & 530 & 930 & 700 & 1,050 & 220 \\
\hline
\end{tabular}


On both occasions summer grazing in the two previous years had a marked beneficial effect on lucerne persistence and yield, and on the control of other species which were predominantly grasses, with Poa annua and Yorkshire fog being most prominent. Grazing in the winter was not quite so effective. Where mowing only was used, the extra spell in the autumn (4H) provided timely shading conditions which reduced the ingress of other species. Seedling grass growth at this time was very noticeable where five cuts were taken $(5 \mathrm{H})$. Grazing in the summer (4HS) was severe, all herbage being eaten down to ground level.

In view of these clear-cut effects, it was decided to extend the scope of the investigation to include a greater variety of grazing practices.

\section{AUTUMN GRAZING TRIAL}

"Wairau" and "Chanticleer" lucernes were sown separately in a series of 1/12-acre plots on a free-draining Ashhurst shallow silt loam in November 1965. These were arranged in three replicated blocks.

Once the lucerne had been established, the whole area was cut and removed as silage or hay each year in November and December at a time when the basal shoots were starting to develop. Subsequently, each year, the plots were fenced and sheep were used as mowers until growth slowed down in May. Apart from treatment 1 plots, grazing took place whenever recovery growth had reached the required height. Sufficient sheep were used to graze off the herbage in three or four days.

The following treatments were used:

(1) Continuous grazing (c)

(2) Grazed whenever herbage reached 3 in. height (3)

(3) Grazed whenever herbage reached 9 in. height (9)

(4) Grazed whenever herbage reached 15 in. height (15)

(5) Grazed once only — on the first occasion that the basal shoots appeared (H 1)

(6) Grazed whenever basal shoots appeared $(\mathrm{H})$

(7) No grazing until winter (NG)

Responses were measured by sampling at the time of the subsequent November and December defoliations. Separations were made into lucerne and other species. Yield data for the years 1967 to 1969 are shown in Tables 2, 3 and 4 and in Figs. 1 and 2. 

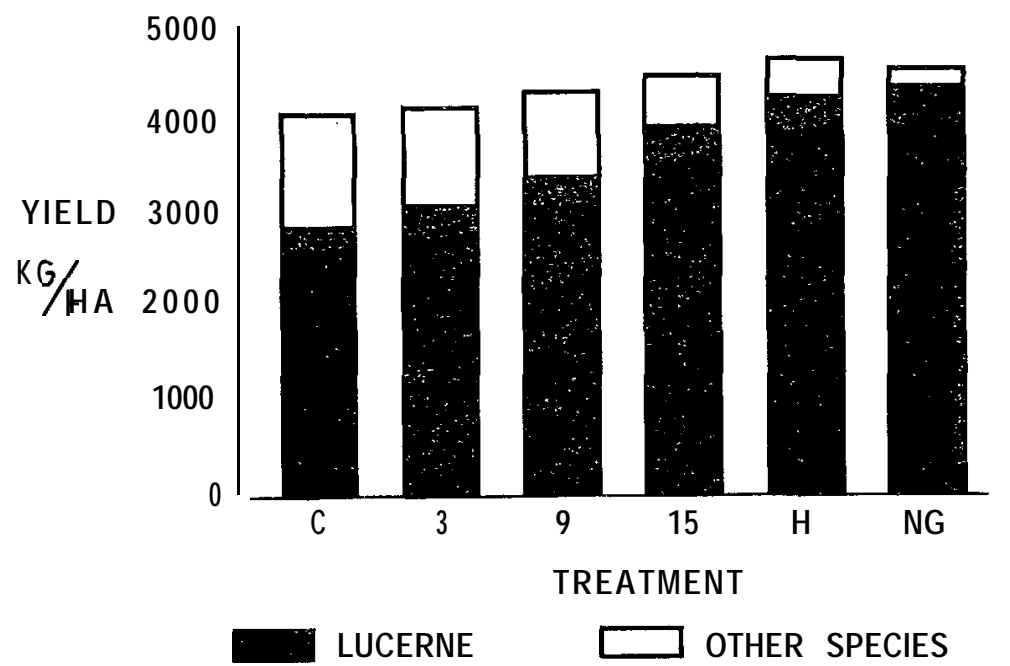

Frg. 1: Dry herbage yield, November 1968.

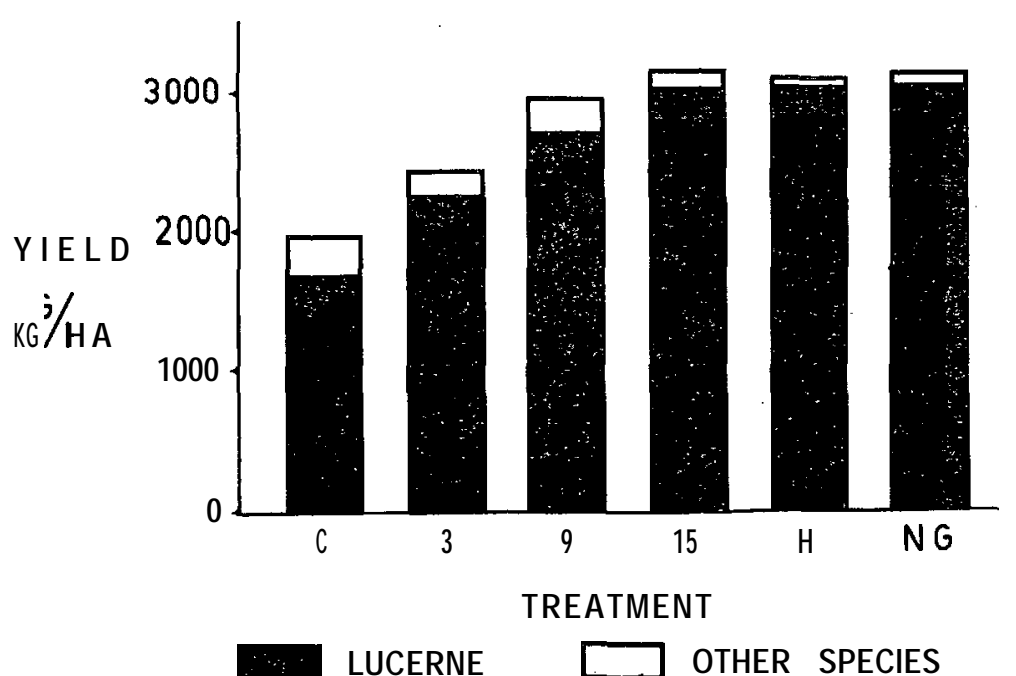

FIG. 2: Dry herbage yield, December 1969. 
TABLE 2: MEAN TOTAL DRY HERBAGE YIELD $(\mathrm{kg} / \mathrm{ha})$

\begin{tabular}{|c|c|c|c|c|c|}
\hline $\begin{array}{l}\text { Previous } \\
\text { Treatment }\end{array}$ & Nov. 1967 & Dec. 1967 & Nov. 1968 & Dec. 1968 & Dec. 1969 \\
\hline C & 3,910 & 4,050 & 4,030 & 2,730 & 1,940 \\
\hline 3 & 4,190 & 4,190 & 4,110 & 3,120 & 2,410 \\
\hline 9 & 4,560 & 3,930 & 4,270 & 3,420 & 2,930 \\
\hline 15 & 4,710 & 4,310 & 4,440 & 3,350 & 3,140 \\
\hline $\mathrm{H1}$ & 4,920 & 4,360 & 4,510 & 3,700 & 3,130 \\
\hline $\mathrm{H}$ & 4,670 & 4,250 & 4,620 & 3,780 & 3,090 \\
\hline $\mathrm{NG}$ & 4,620 & 4,400 & 4,510 & 3,830 & 3,130 \\
\hline LSD $5 \%$ & 570 & NS & NS & 240 & 550 \\
\hline $1 \%$ & NS & NS & NS & 330 & 740 \\
\hline
\end{tabular}

TABLE 3: MEAN LUCERNE DRY HERBAGE YIELD (kg/ha)

\begin{tabular}{|c|c|c|c|c|}
\hline $\begin{array}{c}\text { Previous } \\
\text { Treatment }\end{array}$ & Nov. 1967 & Nov. 1968 & Dec. 1968 & Dec. 1969 \\
\hline$C$ & 2,820 & 2,570 & 2,680 & 1,700 \\
\hline 3 & 2,920 & 3,090 & 3,020 & 2,270 \\
\hline 9 & 3,400 & 3,400 & 3,380 & 2,780 \\
\hline 15 & 4,230 & 3,960 & 3,300 & 3,040 \\
\hline H1 & 4,810 & 4,210 & 3,690 & 3,080 \\
\hline $\mathrm{H}$ & 4,640 & 4,260 & 3,760 & 3,070 \\
\hline NG & 4,620 & 4,370 & 3,830 & 3,070 \\
\hline LSD $5 \%$ & 600 & 570 & 270 & 590 \\
\hline $1 \%$ & 810 & 780 & 360 & 800 \\
\hline
\end{tabular}

TABLE 4: MEAN DRY HERBAGE YIELD OF OTHER SPECIES $(\mathrm{kg} / \mathrm{ha})$

\begin{tabular}{cccccc}
\hline $\begin{array}{c}\text { Previous } \\
\text { Treatment }\end{array}$ & Nov. $\quad 1967$ & Nov. $\quad 1968$ & Dec. & 1968 & Dec. 1969 \\
\hline C & $\mathbf{1 , 0 9 0}$ & 1,160 & 50 & 2 \\
3 & 1,270 & 1,020 & 100 & 140 \\
9 & 1,160 & 880 & 45 & 150 \\
15 & 480 & 490 & 50 & 105 \\
H1 & 110 & 300 & 0 & 50 \\
H & 30 & 360 & 15 & 20 \\
NG & 0 & 135 & 0 & 60 \\
LSD 5\% & 400 & 355 & 50 & 110 \\
$1 \%$ & 545 & 480 & 70 & 150 \\
\hline
\end{tabular}

Note that these three tables contain the combined results of both varieties of lucerne. There was no interaction between varieties and grazing treatments. "Chanticleer" showed higher yields of lucerne in all the comparisons made, but in only two of these were the differences significant, 
The results show that the frequency of grazing had a marked effect on the subsequent yields and composition of the plots. In the first cut in November total yield tended to be similar in all plots, because of the compensating growth of other species where the lucerne was weak (Tables 3 and 4). The second cut each spring (data for December 1968 were representative) was much freer of other species but showed big differences in lucerne yield,

Point analysis of the recovery growth after the November 1968 cut confirmed that the invading species, mainly grasses and clovers, were significantly more prominent in the more frequently grazed plots.

It was not possible to make detailed measurement of the components of yield at the time of all of the above cuts, but in the period following the November 1968 sampling stem counts were taken and stem heights measured.

\section{Stem Counts}

Distinction was made between shoots arising from the crown and those developing on the stubble.

Mean crown shoot and stubble shoot numbers per $0.09 \mathrm{sq}$ metre are given in Table 5.

TABLE 5: MEAN CROWN AND STUBBLE STEM NUMBERS (PER 0.09 SQ. METRE) AND MEAN STEM HEIGHTS (CM) NOVEMBER

\begin{tabular}{cccc}
\hline \multicolumn{3}{c}{27,1968} \\
Previous & Crown Shoot & Stubble Shoot & Mean \\
Treatment & Nos. & Nos. & Stem Height \\
\hline C & 71.4 & 23.1 & 16.1 \\
3 & 72.3 & 19.8 & 17.5 \\
9 & 73.8 & 19.0 & 19.3 \\
15 & 79.8 & 18.3 & 19.5 \\
Hi & 82.5 & 17.7 & 19.6 \\
H & 84.1 & 15.1 & 21.2 \\
NG & 87.5 & 16.4 & 21.2 \\
LSD $5 \%$ & 9.5 & 4.3 & 2.5 \\
$1 \%$ & 12.8 & NS & 3.4 \\
\hline
\end{tabular}

There was no significant difference between treatments in the total numbers of these two types of shoots.

The highest yielding plots were those that produced the greatest number of crown shoots. These results agree with those of Langer and Koeghan (1970) where simulated swards of Wairau lucerne were used. 


\section{Stem Heights}

Stem height measurements were made at random in the crop by means of a calibrated rod on November 25, 1968, 16 'days after defoliation and these are recorded in Table 5.

The crop height at this stage was closely related to the yield of lucerne obtained in December 1968 and it was clear that the treatments grazed more frequently the previous year were adversely affected in regard to the rate of stem elongation.

In 1969, the final season of the trial, some of the plots were used for a masterate thesis and additional measurements were made on these, In particular two of the extreme treatments (3 and $\mathrm{H}$ ) were sampled during the spring growth period of August 8 to November 10 .

Yields followed the same pattern as shown in Tables 2, 3, and 4, partly because of the significantly greater stem height in the $\mathrm{H}$ treatment $(35.4 \mathrm{~cm})$ compared with treatment $3(26.8$ $\mathrm{cm})$. Mean shoot weights showed increasing divergence between treatments as the crop matured (Table 6).

\section{TABLE 6: MEAN SHOOT WEIGHT (G)}

\begin{tabular}{cccccccc}
\hline Treatment & \multicolumn{7}{c}{ Growth Period (days) } \\
& 0 & 14 & 28 & 42 & 56 & 70 & $\mathbf{8 4}$ \\
\hline 3 & 0.034 & 0.050 & 0.095 & 0.186 & 0.355 & 0.585 & 0.760 \\
$\mathrm{H}$ & 0.047 & 0.073 & 0.130 & 0.254 & 0.513 & 0.946 & 11.290 \\
\hline
\end{tabular}

This was influenced by the greater maturity of the shoots in the $\mathrm{H}$ treatment. For both treatments, leaf senescence started approximately 28 days after the August 8 harvest, and in the $\mathrm{H}$ treatment it occurred at a significantly greater level after 42 days. This did not markedly influence shoot weight.

Lightproof covers were placed over areas of defoliated lucerne at this time and the resulting growth measured. The $\mathrm{H}$ treatments grew four times more shoot dry weight and demonstrated their greater reserve capacity.

TABLE 7: MEAN SHOOT NUMBER PER 0.56 SQ. METRE, NOVEMBER 1969

(two weeks after defoliation)

\begin{tabular}{cc}
\hline Treatment & Shoot Nos. \\
\hline 3 & 269.44 \\
$\mathrm{H}$ & 619.77 \\
\hline
\end{tabular}


Following the November 10 defoliation, shoot numbers in the recovery growth were recorded and showed a highly significant difference between the two treatments (Table 7).

\section{CONCLUSIONS}

The lack of persistence of lucerne under mowing in the North Tsiand has long been regarded as its main disadvantage. Furthermore, the ability of the crop to withstand grazing was largely unknown.

The experiments reported here were carried out to determine some of the factors which influence the survival of lucerne and the ingress of other species. It was realized that competition between the two groups of plants depends largely on their relative vigour. In the pilot trial the invading grasses were weakened by a single severe grazing treatment per year. When grazing occurred at the conclusion of a cycie of growth of the iucerne no damage appeared to be done to it and the general effect was to increase lucerne dominance. The use of chemicals to modify botanical composition was not investigated in these experiments.

In addition to weakening invading species, suitable management must retain a high degree of vigour in the lucerne itself. Many trials have shown that, the more frequently crops' are defoliated, the less their production (Tsuma, 1968; Koeghan, 1967). The main experiment has demonstrated that grazing is no different in this respect from any other type of defoliation. The treatments giving the most vigorous lucerne growth were those grazed about the time when basal shoots were starting to elongate. Little reduction in vigour occurred with grazing at $15 \mathrm{in}$. but the more frequently defoliated treatments showed: a marked decline in production. This resulted even though the crop had two long spells in the spring growth period.

The persistence of lucerne in this experiment appeared to bo partly due to the greater density of stems in the longer spelled plots and partly to their more rapid elongation. Even though senescence was greater this was compensated for by an increasingly greater shoot weight as maturity approached. No doubt this stronger competition from the lucerne was induced by the rapid early growth of the stem and greater stem density wherever defoliation took place when the basal buds were about to develop.

Spring mowing with summer and autumn grazing is one general method of management that can be used with lucerne and these experiments have shown that its success depends on the 
length of the recovery period after grazing. Further investigation is necessary to determine whether grazing in the spring period is subject to similar limitations. Limited experience (Tsuma, 1968) would indicate that it is and it appears that lucerne can be a valuable grazing crop in the humid temperate climate of the North Island.

\section{REFERENCES}

Anon.,

pp.

Koeghan, J. M., 1967: In The Lucerne Crop: 117-128. Ed. R. H. M. Langer, A. H. Reed, Wellington.

Langer, R. H. M.; Koeghan, J. M., 1970: Proc. N.Z. Grassld Ass., 32: 98-107.

Tsuma, F., 1968: M.Agr.Sc. Thesis, Massey Univ. N.Z.

\section{DISCUSSION}

Johnston (Palmerston North) asked if there had been any diseases present in the lucerne. Robinson replied that there had been a trace of stem rot in the main experiment during the first summer, but that it had disappeared after the first grazing. There had been some stem nematode infestation in the earlier trial but it had not persisted for long. Lynch (Ruakura) expressed surprise that the intensity of grazing under the set-stocking system had not eliminated the plants completely.? Robinson agreed that there was a surprising lack of serious damage, though growth had been kept to 1 to $1 \frac{1}{2}$ in. Density of the plots did deteriorate in the third year and a greater loss of lucerne would occur. There had been a varietal difference - Chanticleer did not perform as well as Wairau under 'set stocking. There had been no effort made to measure fertilizer requirements under the different systems. A basal dressing of $6 \mathrm{cwt}$ potassic superphosphate was applied over the whole area. Total yields had been in the region of $14,0001 \mathrm{~b} \mathrm{DM} / \mathrm{acre}$. As far as grazing was concerned, an endeavour was made to preselect the time when the crop was about to produce new shoots. It was then grazed in 3 to 4 days at about 200 sheep/acre. Observations did not indicate any damage to young shoots. Gordon (Taupo) asked if there had been any difference in production between 15 in. and hay treatments. Robinson replied that, in the one year for which he had production figures, both systems had the same yield of $13,000 \mathrm{lb}$ DM/acre. 